\title{
Perinatal Al-Quran Sound to Novel Object Recognition Memory and Hippocampal Cell Count
}

\author{
Tryando Bhatara, ${ }^{1}$ Achadiyani, ${ }^{2}$ Uni Gamayani, ${ }^{3}$ Herry Herman ${ }^{4}$ \\ ${ }^{1}$ Department of Histology and Cell Biology, Faculty of Medicine, Universitas Islam Bandung, Bandung, Indonesia, \\ ${ }^{2}$ Department of Biomedical Sciences, Faculty of Medicine, Universitas Padjadjaran, Bandung, Indonesia, \\ 3Department of Neurology, Faculty of Medicine, Universitas Padjadjaran/Dr. Hasan Sadikin \\ General Hospital, Bandung, Indonesia, ${ }^{4}$ Department of Orthopaedic and Traumatology, \\ Faculty of Medicine, Universitas Padjadjaran, Bandung, Indonesia
}

\begin{abstract}
Al-Quran sound as auditory stimulation may influence the development of systems related to memory. This study aimed to investigate the effect of Al-Quran acoustic stimulation to novel object recognition (NOR) memory and amount of hippocampal formation cells at postnatal day (PND) 21 Wistar rats. This study was conducted in September 2016 to January 2017. Adult Wistar rats divided into intervention and control groups were bred at Faculty of Medicine Universitas Islam Bandung. Rat pups in the intervention group were exposed to Quranic sound from postcoital day o to the PND 20. Rats of PND 20 was involved in the NOR test by documenting the value of the duration of exploration of the familiar and novel object. The rats' brains were extracted and processed at Faculty of Medicine Universitas Padjadjaran for cell counting of hippocampal formation stained with hematoxylin-eosin. The results displayed a higher value of $\mathrm{D}_{1}$ (exploration time difference) and a total number of hippocampal formation cells in the Al-Quran groups. These results can be related to the role of the Quranic voice in suggesting higher learning aspects, activating neurogenesis or cell survival transcription factors. However, there was no difference in discrimination index (DI) value between groups which could be indicating inadequate habituation period, interval, testing age, or stress factors. Numerous limitations from this field of research suggest that the biological role of sound stimulation is still in its early stages of development. In conclusion, exposure to perinatal Al-Quran sound may serve as stimulation which enhances learning, memory, neurogenesis or cell survival of hippocampal formation.
\end{abstract}

Key words: Al-Quran, hippocampal formation, memory, sound

\section{Suara Al-Quran Perinatal pada Memori Novel Object Recognition dan Jumlah Sel Hipokampus}

\begin{abstract}
Abstrak
Suara Al-Quran sebagai stimulasi pendengaran diperkirakan dapat memengaruhi perkembangan sistem tubuh terkait memori. Penelitian ini bertujuan mengamati pengaruh stimulasi suara Al-Quran terhadap memori novel object recognition (NOR) dan jumlah sel formasi hipokampus pada tikus Wistar 21 hari setelah lahir (postnatal day/PND). Penelitian ini dilaksanakan pada September 2016 sampai Januari 2017. Tikus Wistar dewasa yang dibagi dalam kelompok perlakuan dan kontrol dibiakkan di Fakultas Kedokteran Universitas Islam Bandung. Anak tikus Wistar dipaparkan dengan suara Al-Quran sejak hari postcoital o sampai anak tikus lahir dan berumur 20 hari setelah lahir (PND 20). Tikus PND 20 dilibatkan dalam tes NOR dengan dokumentasi nilai durasi eksplorasi objek lama dan baru. Otak tikus diproses di Fakultas Kedokteran Universitas Padjadjaran untuk penghitungan jumlah sel formasi hipokampus dengan pewarnaan hematoxylin-eosin. Hasil penelitian ini menunjukkan nilai D1 (perbedaan durasi eksplorasi objek lama-baru) dan jumlah sel formasi hipokampus lebih tinggi pada kelompok perlakuan dengan Al-Quran. Hasil tersebut dapat terkait dengan peran suara Al-Quran dalam aktivasi faktor pertumbuhan atau transkripsi. Namun, tidak terdapat perbedaan bermakna pada nilai indeks diskriminasi antarkelompok yang dapat terkait dengan faktor stres atau kurangnya periode habituasi atau periode uji. Berbagai keterbatasan penelitian ini serta riset di bidang stimulasi embriologi mengindikasikan bahwa peran biologis suara Al-Quran masih harus diteliti lebih lanjut. Simpulan, paparan suara Al-Quran perinatal dapat berlaku sebagai stimulasi yang meningkatkan pembelajaran, memori, neurogenesis atau ketahanan sel formasi hipokampus.
\end{abstract}

Kata kunci: Al-Quran, formasi hipokampus, memori, suara

Received: 8 May 2018; Revised: 30 November 2018; Accepted: 7 December 2018; Published: 31 December 2018

Correspondence: Tryando Bhatara, dr., M.Kes. Department of Histology and Cell Biology, Facuty of Medicine, Universitas Islam Bandung. Jln. Tamansari No. 22, Bandung 40116, West Java, Indonesia. Mobile: +6287823080949 E-mail: tryando.bhatara@gmail. com 


\section{Introduction}

Numerous studies indicate that environmental stimulation has influence in learning and memory through neuronal activity. Sound stimulation may affect neuronal response and amount of cells in the brain through increasing or activating elements of proliferation, growth, and survival. ${ }^{1-3}$

Al-Quran recitation as a form of sound has rhythmic and melodic aspects that may influence the brain through substances and patterns related to information coding, long-term potentiation, and retrieval in learning and memory. Related to auditory stimulation, Al-Quran sound may be capable of increasing the amount or activation of proteins such as calcium-binding protein (CBP), cyclic adenosine monophosphate (cAMP) response element binding protein (CREB) and its downstream transcription factor brain-derived neurotrophic factor (BDNF), each of which has stimulatory roles in of cell proliferation, synaptogenesis, and neuronal growth and survival. ${ }^{4-7}$

This study attempts to observe the effect of Al-Quran as a sound stimulation to novel object recognition (NOR) memory as one type of declarative memory, and the amount of cells in hippocampal formation as an important structure for memory functions at postnatal day (PND) 21 Wistar rats.

\section{Methods}

This study was conducted in September 2016 to January 2017. Eighteen (18) adult female Wistar rats the age of 8-9 weeks, with 200-250 grams of weight were randomized and divided into control and Al-Quran group. Each group was placed in separate rooms, conditioned into mating and breeding, with intervention group exposed to Al-Quran auditory stimulation (Al-Fatihah, AlBaqarah, and Ali Imran respectively) in mp3 format for 3.5 hours once daily from post-coital day $o$ to post-natal day (PND) 20 of the rat pups. The rat pups from both groups were then involved in NOR test for the NOR values to be documented. Breeding and NOR test commenced at the Faculty of Medicine Universitas Islam Bandung (Figure 1).

In NOR test, duration of exploring novel object $\left(\mathrm{T}_{\mathrm{N}}\right)$ and duration of exploring familiar object $\left(\mathrm{T}_{\mathrm{F}}\right)$ documented. The first value for NOR is $\mathrm{D}_{1}$, which is a difference of exploration time studying the novel object substracted by the duration exploring everyday object $\left(\mathrm{T}_{\mathrm{N}}-\mathrm{T}_{\mathrm{F}}\right)$. The second value is the discrimination index (DI), which calculated by $\left(\mathrm{T}_{\mathrm{N}}-\mathrm{T}_{\mathrm{F}}\right) /\left(\mathrm{T}_{\mathrm{N}}+\mathrm{T}_{\mathrm{F}}\right)$. The duration measured in seconds. Positive and negative values indicate a stronger preference for the novel object and the familiar object, respectively. ${ }^{\text {? }}$

The rats terminated, the brains extracted and put into formalin 10\%-phosphate buffered saline (PBS) $\mathrm{pH} 7.4$ and glutaraldehyde $2.5 \%$ overnight then dehydrated in increased concentration of ethanol of $70 \%, 80 \%, 90 \%$, and $100 \%$ for 60 minutes each. Clearing procedure used xylol three times for 15 minutes each at room temperature, and the tissues were afterward infiltrated with liquid paraffin in the incubator with $60^{\circ} \mathrm{C}$ three times for 60 minutes each infiltration.
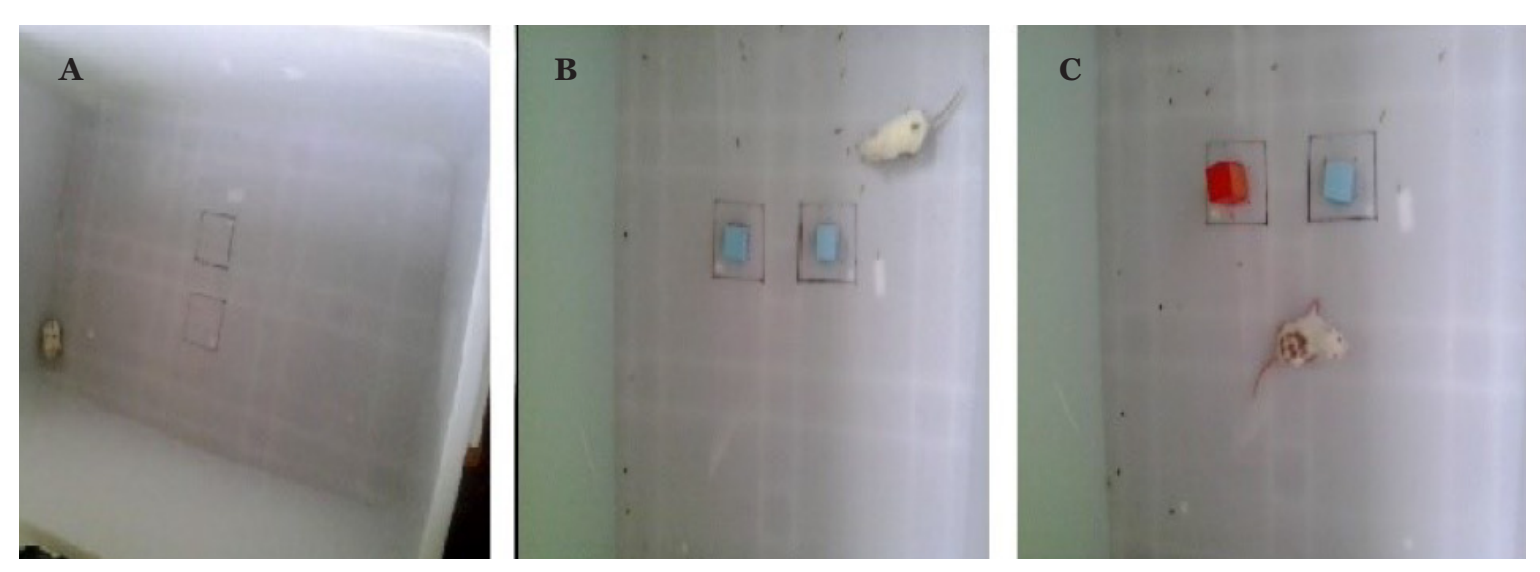

Figure 1 The Novel Object Recognition Test of Rat Pups after the Intervention

A. Habituation phase, empty arena; B. Training phase, arena with two identical objects; C. Test phase, arena with one familiar object and one novel object. PND 20 rats are exploring each arena in 3 phases consecutively with 3 minutes for each stage and 30 minutes for the interval between each step 
Table Results of NOR Test and Hippocampal Formation Cell Counting

\begin{tabular}{lccc}
\hline \multirow{2}{*}{ Variable } & \multicolumn{2}{c}{ Groups } & \multirow{2}{*}{ p Value } \\
\cline { 2 - 3 } & Al-Quran & Control & \\
\hline Exploration time difference $\left(\mathrm{D}_{1}\right)^{*}$ & 6.05 & & 0.0491 \\
$\quad$ Median & $0-7.19$ & 0 & \\
$\quad$ Interquatile & & $0-0.415$ & \\
Discrimination index (DI) & 0.355 & & 0.1311 \\
$\quad$ Median & $0-0.77$ & 0 & \\
$\quad$ Interquatile & & $0-0.07$ & \\
Hippocampal formation cell count & $1,449.88$ & $1,054.38$ & \\
$\quad$ Mean & 182.08 & 150.32 & \\
$\quad$ Standard deviation & & & \\
\hline
\end{tabular}

*in seconds

The membranes were then embedded in liquid paraffin and cooled in room temperature to make paraffin blocks. ${ }^{8}$

Paraffin blocks were sliced coronally by rotary microtome with the thickness of $4 \mu \mathrm{m}$ until reaching hippocampal formation. The targeted slices then put at warm water surface of $45^{\circ} \mathrm{C}$, put in object glass coated by poly-L-lysine, dried vertically in room temperature before putting in slide warmer at $37^{\circ} \mathrm{C}$ horizontally overnight, and stored in a box at room temperature before stained with hematoxylin-eosin (HE). ${ }^{8}$

Tissue processing organized at Faculty of Medicine Universitas Padjadjaran. Cell counting of hippocampal formation is done using Optilab light microscope with a magnification of 400 times and Image Raster computer program. Data analyzed using Stata computer program with the significance of $\mathrm{p} \leq 0.05$. From the Shapiro-Wilk test, NOR values analyzed by Mann-Whitney, and unpaired $\mathrm{t}$ test examined hippocampal formation cell count.

This research was carried out by considering the ethical issues of $3 \mathrm{R}$ (replacement, reduction, and refinement) principles. The animals underwent adaptation, regular light-dark cycle, and given intervention during the late period to provide comfort and minimize stress factor of the experimental animals. This research had approved by the Health Research Ethics Committee of Faculty of Medicine Universitas Padjadjaran with the ethical clearance number: 839/UN6.C1.3.2/KEPK/PN/2016.

\section{Results}

Mann-Whitney analysis displayed the difference in $\mathrm{D}_{1}$ in rat pups exposed to Al-Quran sound stimulation, yet no significant difference in DI. Cell counting results by $t$ test showed the higher
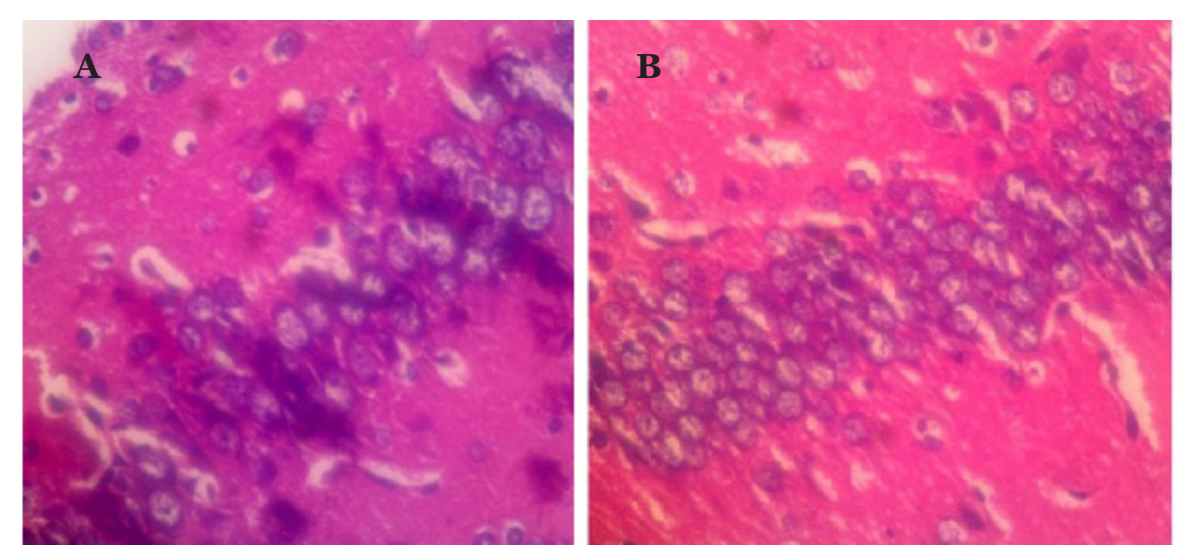

Figure 2 Hippocampal Formation of PND 21 Wistar Rats Stained with Hematoxylin Eosin A. Control group, B. Intervention group exposed to Al-Quran sound stimulation 
amount of cells in the hippocampal formation of rat pups exposed to Al-Quran sound (Table).

Images from the Optilab light microscope and the Raster Image computer program showed a higher cell count in the hippocampal formation of an animal group with exposure of Al-Quran sound stimulation (Figure 2).

\section{Discussion}

Al-Quran sound may affect brain growth and development through numerous mechanisms such as perceptual processing of its acoustic features such as pitch, timbre, melody, rhythm, intensity, and texture. Rhythmical sound stimulation was reported to activate cortical, subcortical and intermodal areas, which may relate to higher performance in tasks involving declarative memory. ${ }^{9-10}$

This study involved intervention by the sound of Al-Quran recited by specific rules affecting specific anatomical sites for verbal accuracy and length of pronounced letters in each part of recitation. One study resulted in higher alpha and theta oscillations in groups listening to Al-Quran, whereas alpha and theta power are related to retrieval, cognitive, and memory process. The recitation rules emphasized Al-Quran sound as rhythmic auditory stimulation. The result of this study supports the notion from previous observations that rhythmic sounds displayed influence toward learning and memory. ${ }^{1-3,11}$

Conscious recollection of facts and conditions termed declarative memory, which includes recognition memory. Recognition memory is closely related to the function of the medial temporal lobe, including hippocampal formation. Recognition memory in experimental animals observed through various neurobehavioral tasks, such as NOR task commenced in this study., ${ }^{7,12}$

The NOR task has the concept of exploration as an essential aspect. Animals can learn by exploring objects, with the term of exploration defined as directing the snout towards the object by the distance of 2 centimeters or less, sniffing or touching object using the snout. Activities of running around, climbing or sitting at the object excluded from the terminology of exploration. The duration of the animal's exploration of the novel object $\left(\mathrm{T}_{\mathrm{N}}\right)$ and the length of the animal's exploration of the familiar object $\left(\mathrm{T}_{\mathrm{F}}\right)$ documented as two distinct components used for two central values of NOR task.?
$\mathrm{D}_{1}$ is total time spent by the animal to explore the new object, substracted from the full time devoted to examining familiar object $\left(\mathrm{T}_{\mathrm{N}}-\mathrm{T}_{\mathrm{F}}\right)$. A positive value indicates a stronger preference for the novel object, and a negative value shows stronger inclination towards familiar object. ${ }^{7}$

In this study, we observed the higher value of $\mathrm{D}_{1}$ in the group exposed to the sound of Al-Quran, noting shorter learning time of objects explored. During the NOR procedure, exposure of animals to novel objects can trigger labile phase that required the stabilization of memory, which is closely related to the reorganization of memory to open the access for new information to blend with the previous memory structure. The display of longer exploration time of novel object implied a shorter time required for memory stabilization of familiar object previously explored, enabling the experimental animals to switch the exploration from familiar to novel object more quickly. These may also relate to increased alpha and theta power in the brain associated with Al-Quran sound exposure, oscillation patterns which indicate the process of encoding new information and long-term potentiation (LTP) that participates in memory aspects..$^{3-5,7}$

However, we observed no significant difference of DI between intervention and control group, indicating lack of distinction in the discriminating capacity of new and old information. DI is the value of $\mathrm{D}_{1}$ divided by the amount of time spent exploring novel and familiar object $\left[\left(\mathrm{T}_{\mathrm{N}}-\mathrm{T}_{\mathrm{F}}\right) /\right.$ $\left.\left(\mathrm{T}_{\mathrm{N}}+\mathrm{T}_{\mathrm{F}}\right)\right]$. Various factors may contribute to this result, one of which is olfactory stress factors experienced from the previous batch of animals tested. Another factor which possibly affected the test is a relatively long interval between each phase may be followed by memory degradation. An analysis stated that NOR memory might reduce as a result of interval duration between each stage reaching 10 minutes or more, which could contribute as an inhibiting factor..$^{14,15}$

Another factor which may influence this result is the organ and cellular development. One study involving NOR procedure to PND 18 rat pups, resulted in lower NOR values compared to adult animals. Previous researchers showed that optimal NOR procedure could be displayed starting from PND 25-30, older than the ones in this study. Thus, a lack of difference in intervention and control groups in this study may also be related to sub-optimal growth processes in the brain such as neurogenesis, synaptogenesis, 
and maturation of structures connected to memory. ${ }^{14,15}$

Hippocampal formation is a bilateral neuronal structure within the medial temporal lobe, which plays a substantial role in declarative memory. It receives afferent pathways from the entirety of cortical association areas and processes the information through various aspects such as encoding, intermodal sensory association, convergence, and memory consolidation. ${ }^{16}$

Sound stimulation from the prenatal period is recognized to have a role in brain function. Previous reports stated that sensory stimulation from early lifespan is capable of inducing long-term plasticity and also elevates proteins related to neuronal development, activation, and stabilization such as calcium-binding protein (CBP), cAMP response element binding protein (CREB), and brain-derived neurotrophic factor (BDNF). This study displays a higher cell count in the hippocampal formation of an animal group with exposure of Al-Quran sound stimulation, which supports those reports from previous researches. Higher cell count in Quranstimulated pups may relate to the effect of rhythmical and melodious aspects of Al-Quran sound toward various factors of brain growth and development, such as proneural genes and transcriptional mediators of neurogenesis or survival of hippocampal formation cells..$^{1-5,13,16,17}$

There was a shorter time of novel object recognition learning and neurogenesis or cell survival reflected in higher values of exploration time difference $\left(\mathrm{D}_{1}\right)$ and amount of hippocampal formation cells after Al-Quran auditory stimulation since prenatal period. However, there was no difference in discrimination index (DI) which may imply inhibition of discrimination capabilities or memory degradation related to the small age of intervention onset or interval duration, stress factors, and limitations in time documentation of NOR procedure. Nevertheless, the research field regarding Al-Quran auditory stimulation and its biological consequences is still in its early phases of development, opening itself for further scientific exploration.

\section{Conclusions}

Exposure to perinatal Al-Quran sound may serve as stimulation which enhances learning, memory, neurogenesis or cell survival of hippocampal formation.

\section{Conflict of Interest}

The authors declare no conflict of interests.

\section{Acknowledgement}

The author's thanks to the Educational Fund Management Institution (Lembaga Pengelola Dana Pendidikan/LPDP) Ministry of Finance Republik of Indonesia for financial support and Faculty of Medicine of Padjadjaran University and Faculty of Medicine of Bandung Islamic University for permission and facilities of this study.

\section{References}

1. Kim CH, Lee SC, Shin JW, Chung KJ, Lee SH, Shin MS, et al. Exposure to music and noise during pregnancy influences neurogenesis and thickness in motor and somatosensory cortex of rat pups. Int Neurourol J. 2013;17(3):107-13.

2. Chaudhury S, Wadhwa S. Prenatal auditory stimulation alters the levels of CREB mRNA, p-CREB and BDNF expression in chick hippocampus. Int $J$ Dev Neurosci. 2009;27(6):583-90.

3. Shekha MS, Hassan AO, Othman SA. Effects of Quran listening and music on electroencephalogram brain waves. Egypt $J$ Exp Biol (Zool). 2013;9(1):119-21.

4. Klimesch W. EEG alpha and theta oscillations reflect cognitive and memory performance: a review and analysis. Brain Res Rev. 1999;29(2-3):169-95.

5. Sigala R, Haufe S, Roy D, Dinse HR, Ritter P. The role of alpha-rhythm states in perceptual learning: insights from experiments and computational models. Front Comput Neurosci. 2014;8:36.

6. Oliveira AMM, Hawk JD, Abel T, Havekes R. Post-training reversible inactivation of the hippocampus enhances novel object recognition memory. Learn Mem. 2010;17(3):155-60.

7. Antunes M, Biala G. The novel object recognition memory: neurobiology, test procedure, and its modifications. Cogn Process. 2012;13(2):93-110.

8. Irawan V. Efek protektif ekstrak etanol pegagan (Centella asiatica (L.) Urban) terhadap proliferasi sel formasi hipokampus 
tikus dewasa pada kondisi stres kronis [master's thesis]. Yogyakarta: Universitas Gadjah Mada; 2012.

9. Peretz I, Zatorre RJ. Brain organization for music processing. Annu Rev Psychol. 2005;56:89-114.

10. Limb CJ. Structural and functional neural correlates of music perception. Anat Rec A Discov Mol Cell Evol Biol. 2006;288(4):43546.

11. Reza F, Begum $\mathrm{T}$, Ahmed AL, Omar H, Muzaimi M, Abdullah JM. Insights from the preliminary autocorrelation analysis of low frequency neuronal oscillations during Quran listening. ASM Sci J. 2012;6(1):39-45.

12. Squire LR, Zola SM. Structure and function of declarative and nondeclarative memory systems. Proc Natl Acad Sci USA. 1996;93(24):13515-22.

13. Koelsch S, Siebel WA. Towards a neural basis of music perception. Trends Cogn Sci.
2005;9(12):578-84.

14. Broadbent NJ, Squire LR, Clark RE. Spatial memory, recognition memory, and the hippocampus. Proc Natl Acad Sci USA. 2004;101(40):14515-20.

15. Reger ML, Hovda DA, Giza CC. Ontogeny of rat recognition memory measured by the novel object recognition task. Dev Psychobiol. 2009;51(8):672-8.

16. Amara D, Lavenex P. Hippocampal neuroanatomy. In: Andersen P, Morris R, Amaral D, Bliss T, O'Keefe J, editors. The hippocampus book. New York: Oxford University Press, Inc; 2009. p. 37-40.

17. Kim $\mathrm{H}$, Lee $\mathrm{MH}$, Chang HK, Lee TH, Lee $\mathrm{HH}$, Shin MC, et al. Influence of prenatal noise and music on the spatial memory and neurogenesis in the hippocampus of developing rats. Brain Dev. 2006;28(2):10914. 